\title{
GENETIC HETEROGENEITY OF HISTIDINEMIA DETECTED BY SCREENING NEWBORN INFANTS IN JAPAN
}

\author{
Yasuhiro Kuroda, Toshiyuki Watanabe, Michinori Ito, Eiji Takeda, \\ Kenji Toshima, and Masuhide Miyao \\ Department of Pediatrics, School of Medicine, Tokushima University, \\ Kuramoto-cho, Tokushima 770, Japan
}

\begin{abstract}
Summary Eleven patients with histidinemia, detected by screening newborn infants, were tentatively classified into two groups on the basis of their skin histidase activity: those with activity of less than $10 \%$ (group 1), and those with activity of about $20 \%$ (group 2) of the normal value. One of the patients in group 2 had two histidinemic siblings who were also classified into group 2. The skin histidase of the two histidinemic siblings were found to have altered kinetic properties. The skin histidase activities of the 22 parents of the histidinemic patients in groups 1 and 2 ranged from 26 to $82 \%$ and from 45 to $79 \%$, respectively, of the average control value. All the 16 parents of the eight patients in group 1 and the six parents of the three probands of group 2 could be distinguished from the patients in groups 1 and 2, respectively, by their skin histidase activity as well as fasting level of serum histidine. In addition, 20 of 22 parents could be distinguished from normal controls by their skin histidase activity. However, two fathers of patients in groups 1 and 2 seemed to be normal, although the mothers were presumably heterozygous carriers.

These results suggest that there is genetic heterogeneity in histidinemia detected by screening newborn infants in Japan. The results also suggest that some cases of histidinemia exhibit different mode of inheritance, although most of histidinemia is autosomal recessive.
\end{abstract}

\section{INTRODUCTION}

Histidinemia is characterized by an increase in concentration of histidine in blood and urine and deficiency of histidase [histidine ammonia lyase, EC 4.3.1.3] activity in the tissues. However, it is probable that histidinemia is not a single genetic disease, because variations are found in the clinical features and biochemical findings in cases with histidinemia. Woody et al. (1965) reported three mentally retarded siblings with deficient liver histidase activity but with normal skin histidase

Received March 1, 1983 
activity. Auerbach et al. (1969), Bruckman et al. (1970) and Anakura et al. (1975) reported histidinemic patients who showed normal intelligence with moderately increased serum histidine levels and urocanic acid levels in the sweat and partially impaired skin histidase activity.

Recently, Kuroda et al. (1980) reported that seven patients with histidinemia, detected by screening newborn infants and two sibs with histidinemia could be classified into two groups on the basis of their skin histidase activity: those with activities of less than $10 \%$ (group 1) and of about $20 \%$ (group 2) of the normal control value.

In this work, using a sensitive assay method, we analyzed the kinetic properties of skin histidase of histidinemic patients in group 2 and parents of patients in groups 1 and 2, and measured the skin histidase activities and the fasting levels of serum histidine in histidinemic patients and their parents to investigate genetic heterogeneity of histidinemia.

\section{MATERIALS AND METHODS}

\section{Subjects}

Eleven histidinemic families were studied. The eleven histidinemic probands were detected by screening newborn infants. One proband had two histidinemic sibs. All the patients are developing normally. Twenty-two parents of the 11 histidinemic probands were also investigated. All the parents are apparently mentally, physically and socially normal and were 24 to 39 years old. None of the parents had a consanguineous marriage.

\section{Laboratory procedures}

Histidase activity in the skin. Small pieces of cuticle were removed from the eponychial area of the finger with a surgical knife. Homogenates $(1 \%, w / v)$ were prepared by grinding the tissue with $0.01 \mathrm{~m}$ pyrophosphate buffer, $\mathrm{pH} 9.2$, containing $6 \mathrm{~mm}$ mercaptoethanol in a glass homogenizer. Skin histidase activities were determined by the method of Kuroda et al. (1979). The reaction mixture for assay of histidase, consisting of $10 \mu \mathrm{l}$ of $0.1 \mathrm{M}$ pyrophosphate buffer, $\mathrm{pH} 9.2$, and $5 \mu \mathrm{l}$ of $16.7 \mathrm{~mm}\left[\mathrm{U}-{ }^{14} \mathrm{C}\right]$ histidine purified by paper chromatography (spec. act., $0.5 \mathrm{mCi}$ / $\mathrm{mmol}$ ) with (experimental) or without (control) $10 \mu$ l of homogenate of human stratum corneum, was incubated at $37^{\circ} \mathrm{C}$. Each sample was assayed in duplicate. After incubation, the control and experimental mixtures were transferred to an ice bath and $10 \mu$ of homogenate was added to the control mixtures. The entire reaction mixtures were then rapidly applied to Toyo No. 50 chromatography paper on which $20 \mu$ of $0.18 \mathrm{~mm}$ urocanic acid had been applied. The paper was developed with butanol/acetic acid/water (12:3:5, by vol.) for 2 to $3 \mathrm{hr}$ by the ascending method to separate urocanic acid from histidine. Then the paper was dried and urocanic acid was located under an ultra-violet lamp. The spots of urocanic acid were cut out and placed in $10 \mathrm{ml}$ of scintillator solution composed of 2 parts of toluene and 1 part of absolute ethanol with $4 \mathrm{~g} /$ liter 2,5-diphenyloxazole (PPO) 
and $0.1 \mathrm{~g} /$ liter 1,4-bis-2-(5-phenyloxazolyl) benzene (POPOP) and radioactivity was counted directly in a liquid scintillation counter. Enzyme activity was calculated from the radioactivity.

Heat denaturation of skin histidase. A mixture of $10 \mu \mathrm{l}$ of the supernatant of a skin homogenate $(2 \%, \mathrm{w} / \mathrm{v})$ and $10 \mu \mathrm{l}$ of $0.1 \mathrm{~m}$ pyrophosphate buffer, $\mathrm{pH} 9.2$, was incubated at $55^{\circ} \mathrm{C}$ for $6 \mathrm{~min}$. Then $5 \mu \mathrm{l}$ of $16.7 \mathrm{~mm}$ [U- $\left.{ }^{14} \mathrm{C}\right]$ histidine was added for assay of histidase activity.

Determination of serum histidine. Blood samples were taken in the morning after overnight fasting. The fasting serum histidine level was measured fluorometrically by the method of Gerber (1970).

Skin histidase activities and fasting serum histidine levels were determined at different times.

\section{RESULTS}

The skin histidase activities of the thirteen histidinemic patients are shown in Table 1. The activities were markedly reduced in all the patients, but three probands and two affected siblings of one of the probands had significantly higher activity than the other eight. Therefore, the thirteen patients were classified into two groups on the basis of their skin histidase activities.

As shown in Table 2, the skin histidase activities of cases $2 b$ and $2 c$ in group 2 were more sensitive to heat denaturation than those of their parents, three parents of patients in group 1 and controls. Incubation for $6 \mathrm{~min}$ at $55^{\circ} \mathrm{C}$ resulted in about $70 \%$ loss of activity in the samples from these patients, but only $40 \%$ loss of activity in those from controls. In contrast, the heat sensitivity of the enzyme activity of case 1 of group 2 did not differ significantly from that of controls.

The $\mathrm{pH}$ optimum curves of skin histidase activity of cases $2 \mathrm{~b}$ and $2 \mathrm{c}$ in group 2 were similar to those of controls (data not shown). The enzyme had a $\mathrm{pH}$ optimum at about 8.5. The Michaelis constant $\left(K_{\mathrm{m}}\right)$ of skin histidase of the patients for histidine was approximately $2.5 \mathrm{~mm}$, which was the same as that of controls (data not shown).

The skin histidase activities of the 22 parents of histidinemic patients in groups 1 and 2 are shown in Table 3 . In group 1, the activities of the parents of patients varied from 2.39 to $7.64 \mu \mathrm{mol} / \mathrm{hr}$ per $\mathrm{g}$ of skin (mean and standard deviation, $4.03 \pm$ 1.31). The activities of fifteen of the sixteen parents of the patients in group 1 ranged between the values for the patients in group 1 and normal subjects, while the value of the father of case 8 was within the normal range.

In group 2, the activities of the parents varied from 4.22 to $7.43 \mu \mathrm{mol} / \mathrm{hr}$ per $\mathrm{g}$ of skin (mean, 5.51 1.16). The activities of five of the six parents ranged between the values for patients in group 2 and normal subjects, while the activity of the father of case 3 was normal.

The skin histidase activities of the parents of the patients in group 2 overlapped 
Table 1. Skin histidase activities and the fasting levels of serum histidine in the patients with histidinemia and normal controls.

\begin{tabular}{|c|c|c|c|c|c|c|}
\hline & \multirow{2}{*}{ Case No. } & \multirow{2}{*}{$\operatorname{Sex}$} & \multicolumn{2}{|c|}{$\begin{array}{c}\text { Skin histidase } \\
\text { ( } \mu \mathrm{mol} \text { urocanate/hr/g skin) }\end{array}$} & \multicolumn{2}{|c|}{$\underset{(\mathrm{mg} / \mathrm{d} \mathrm{l})}{\text { Serum histidine }}$} \\
\hline & & & Mean \pm S.D. & Range & Mean $\pm S . D$ & Range \\
\hline \multirow[t]{15}{*}{ Patients } & Group 1 & & $0.28 \pm 0.18^{*}(8)^{\mathrm{a}}$ & $0.00-0.50$ & $12.9 \pm 1.7^{*}(7)^{\mathrm{a}}$ & $10.5-15.8$ \\
\hline & 1 & $\mathrm{f}$ & $0.45 \pm 0.39(2) b$ & & $12.4 \pm 3.2(3) b$ & \\
\hline & 2 & $\mathrm{~m}$ & $0.21 \pm 0.28$ & & $15.8 \pm 2.0$ & \\
\hline & 3 & $\mathrm{f}$ & $0.45 \pm 0.39$ & & $10.5 \pm 1.6(4)$ & \\
\hline & 4 & $\mathrm{~m}$ & $0.27 \pm 0.37$ & & $14.3 \pm 1.7$ & \\
\hline & 5 & $\mathrm{~m}$ & 0.27 & & - & \\
\hline & 6 & f & $0.12 \pm 0.18 \quad(2)$ & & $11.7 \pm 1.1$ & \\
\hline & 7 & $\mathrm{~m}$ & 0.00 & & $12.7 \pm 0.7$ & \\
\hline & 8 & f & 0.50 & & $13.1 \pm 3.6$ & \\
\hline & Group 2 & & $2.21 \pm 0.38 \quad(5)^{2}$ & $1.76-2.73$ & $7.8 \pm 1.6(5)^{\mathrm{a}}$ & $6.1-9.5$ \\
\hline & 1 & f & $1.76 \pm 0.17(3)^{b}$ & & $9.0 \pm 0.8(6)^{\circ}$ & \\
\hline & $2 a$ & f & $2.13 \pm 0.02$ (2) & & $9.5 \pm 2.5 \quad(3)$ & \\
\hline & $2 b$ & $\mathrm{~m}$ & 2. 43 & & $8.1 \pm 1.0$ & \\
\hline & $2 c$ & $\mathrm{~m}$ & 2.73 & & $6.1 \pm 1.3$ & \\
\hline & 3 & $\mathrm{~m}$ & 1.99 & & $6.1 \pm 1.1$ (2) & \\
\hline \multirow[t]{4}{*}{ Normal controls } & $1-11$ mo & & $9.49 \pm 4.14(10)$ & 4. $39-12.59$ & $2.5 \pm 0.3(5)^{a}$ & 2. $3-3.0$ \\
\hline & $1-5 \mathrm{yr}$ & & $12.53 \pm 2.81$ & $7.90-16.21$ & $2.8 \pm 0.2(10)$ & 2. $4-3.0$ \\
\hline & $6-15 \mathrm{yr}$ & & $10.98 \pm 1.93$ & $8.32-13.64$ & $3.1 \pm 0.3(10)$ & $2.6-3.2$ \\
\hline & adult & & $9.36 \pm 2.04(24)$ & $6.40-14.42$ & $2.5 \pm 0.2(18)$ & $2.1-3.5$ \\
\hline
\end{tabular}

The skin histidase activities and the fasting serum histidine levels were determined at different times. The fasting levels of serum histidine in the patients with histidinemia were measured before administration of a low-histidine diet. a Number of individuals, $b$ Number of assays. * Significantly different from group 2.

Table 2. Heat denaturation of skin histidase.

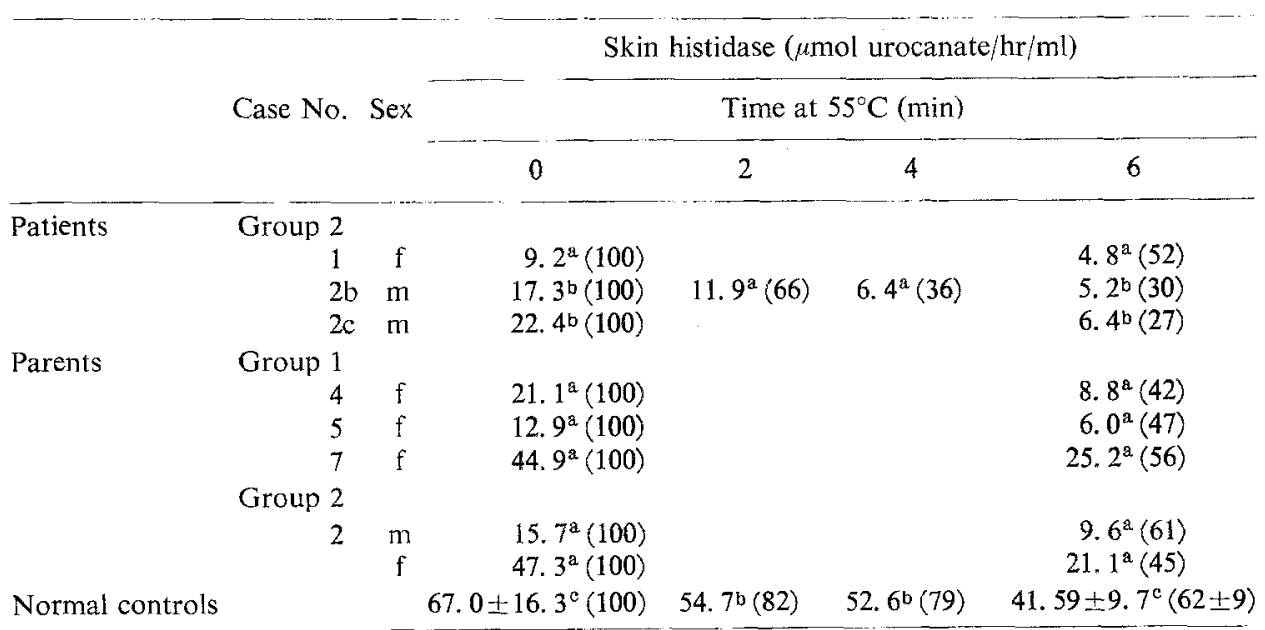

Number of assays or individuals ${ }^{a} 1$, b 2 (mean given), ${ }^{\mathrm{c}} 6$ (mean \pm S.D. given). Percentages of activities of the supernatant kept at $0^{\circ} \mathrm{C}$ are shown in parentheses. 
Table 3. Skin histidase activities and fasting levels of serum histidine in the parents of histidinemic patients in groups 1 and 2 .

\begin{tabular}{|c|c|c|c|c|c|c|}
\hline & \multirow{2}{*}{ Case No. } & \multirow{2}{*}{ Sex } & \multicolumn{2}{|c|}{$\begin{array}{c}\text { Skin histidase } \\
\text { ( } \mu \mathrm{mol} \text { urocanate/hr/g skin) }\end{array}$} & \multicolumn{2}{|c|}{$\begin{array}{l}\text { Serum histidine } \\
(\mathrm{mg} / \mathrm{dl})\end{array}$} \\
\hline & & & Mean $\pm S . D$. & Range & Mean $\pm S . D$ & Range \\
\hline \multirow[t]{24}{*}{ Parents } & Group 1 & & $4.03 \pm 1.31^{*}(16)^{2}$ & 2. $39-7.64$ & $2.9 \pm 0.6^{*}(16)^{2}$ & $1.9-4.0$ \\
\hline & 1 & $\mathrm{~m}$ & 3.12 & & $(1)^{b}$ & \\
\hline & & $\mathrm{f}$ & 4.09 & & 2.4 & \\
\hline & 2 & $\mathrm{~m}$ & 3.81 & & 3.5 & \\
\hline & & $\mathrm{f}$ & 2.44 & & 3.0 & \\
\hline & 3 & $\mathrm{~m}$ & 5.45 & & 3.5 & \\
\hline & & $f$ & 3.84 & & $2.7 \pm 0.9$ & \\
\hline & 4 & $\mathrm{~m}$ & 3.89 & & 2.7 & \\
\hline & & $\mathrm{f}$ & 2. 39 & & 2.3 & \\
\hline & 5 & $\mathrm{~m}$ & 3.16 & & 4.0 & \\
\hline & & $\mathrm{f}$ & 4.62 & & 1.9 & \\
\hline & 6 & $\mathrm{~m}$ & 5,42 & & 3.1 & \\
\hline & & $f$ & 3.45 & & $3.3 \pm 1.3(2)$ & \\
\hline & 7 & $\mathrm{~m}$ & 4.37 & & - & \\
\hline & & $\mathrm{f}$ & 3.61 & & $3.3 \pm 0.7$ & \\
\hline & 8 & $\mathrm{~m}$ & $7.64 \pm 1.31$ & & $2.5 \quad$ (1) & \\
\hline & & $f$ & $3.16 \pm 0.34$ & & $2.3 \pm 0.4$ (2) & \\
\hline & Group 2 & & $5.51 \pm 1.16(6)^{2}$ & 4. $22-7.43$ & $2.7 \pm 0.8(6)^{\mathrm{a}}$ & $1.9-4.0$ \\
\hline & 1 & $\mathrm{~m}$ & 4.22 & & $(1)^{b}$ & \\
\hline & & $f$ & $5.11 \pm 0.88$ & & 2.3 & \\
\hline & 2 & $\mathrm{~m}$ & $6.10 \pm 1.42$ & & 2.9 & \\
\hline & & f & $4.61 \pm 2.42$ & & $2.0 \pm 0.1$ & \\
\hline & 3 & $\mathrm{~m}$ & $7.43 \pm 0.76$ & & $4.0 \quad$ (1) & \\
\hline & & $f$ & $5.60 \pm 1.65$ & & $2.8 \pm 1.1$ (2) & \\
\hline
\end{tabular}

The skin histidase activities and fasting serum histidine levels were determined at different times. « Number of individuals, $\$$ number of assays. * Not significantly different from parents in group 2 ( $p>0.05$ ) but significantly different from patients in group 2.

with those of the parents of the patients in group 1, and there was no significant difference between the two groups ( $p>0.05$ ). In addition, the activities of some fathers of the patients in group 1 overlapped with those of the patients in group 2.

The fasting serum histidine concentrations of the 22 parents are shown in Table 3. Values for parents of patients in group 1 varied from 1.9 to $4.0 \mathrm{mg} / \mathrm{dl}$ (mean, $2.9 \pm 0.6$ ), while those for parents of patients in group 2 varied from 1.9 to $4.0 \mathrm{mg} / \mathrm{dl}$ (mean, $2.7 \pm 0.8$ ). The serum histidine levels of the parents in group 2 were not significantly different from those of the parents in group $1(\mathrm{p}>0.05)$. Moreover, the serum histidine levels of the parents of the patients in both groups were significantly lower than those of patients in group 2, which were measured before administration of a low-histidine diet, and none of their values overlapped with those of patients in group 2. However, the fasting serum histidine levels of the 


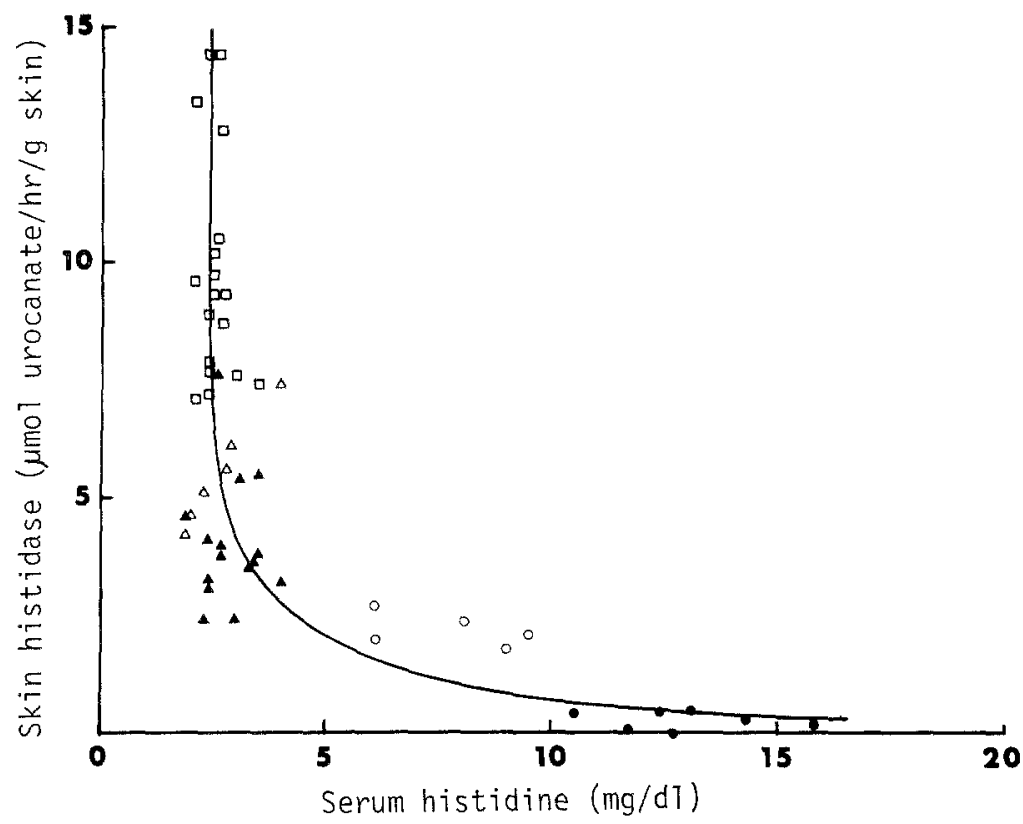

Fig. 1. Skin histidase and serum histidine, Skin histidase activities and fasting serum histidine levels were determined at different times. The fasting levels of serum histidine in the patients with histidinemia were measured before administration of a low-histidine diet. Closed and open circles, closed and open triangles and open squares show values for patients in groups 1 and 2, parents in groups 1 and 2 and normal adults, respectively.

parents were not significantly different from those of normal controls.

Values for skin histidase activities and fasting serum histidine concentrations shown in Tables 1 and 3 are plotted in Fig. 1. The serum histidine concentrations were low with histidase activities of about $3 \mu \mathrm{mol} / \mathrm{hr}$ per $\mathrm{g}$ of skin but began to rise significantly at lower values.

All the 16 parents of the patients in group 1 and the six parents of the patients in group 2 could be clearly distinguished from the patients in groups 1 and 2, respectively, by their skin histidase activities as well as fasting serum histidine levels. In addition, 20 out of 22 parents could be distinguished from normal control by their skin histidase activities.

\section{DISCUSSION}

A nationwide screening of newborn infant for inborn errors of metabolism in Japan revealed an unexpectedly high incidence of histidinemia has been found (Tada et al., 1984). However, it is probable that histidinemia is not a single genetic disease, because the clinical features and biochemical findings in cases with histidinemia 
vary. We developed a sensitive method for assay of skin histidase with ${ }^{14} \mathrm{C}$-histidine as substrate and reported that patients with histidinemia could be classified into two groups on the basis of their skin histidase activity: those with activities of less than $10 \%$ (group 1) and those with activities of about $20 \%$ (group 2 ) of the normal values (Kuroda et al., 1979, 1980). In this work, using this sensitive assay method, we analyzed the kinetic properties of skin histidase of three histidinemic patients in group 2 and five parents of patients in groups 1 and 2, and measured the skin histidase activities of thirteen histidinemic patients and their parents to investigate genetic heterogeneity of histidinemia.

In Fig. 1, the fasting serum histidine levels are plotted against the skin histidase activities, irrespective of age, sex or genotype. The data show that the fasting serum histidine concentrations are low when skin histidase activities are more than approximately $3 \mu \mathrm{mol} / \mathrm{hr}$ per $\mathrm{g}$ of skin. The histidine concentrations begin to rise significantly at lower histidase activities. A similar relation was found between the histidase activities and histidine levels in the liver of histidinemic mice (Kacser et al., 1973).

The skin histidase activities of five patients in group 2 were between those of the patients in group 1 and the parents of the patients in groups 1 and 2 , though the activities of these five patients in group 2 were close to the lower values for the parents of patients in group 1 and some of the latter overlapped with the former. The eponychial area of the finger tends to be contaminated with many kinds of substances, which may influence the skin histidase activity. However, the fasting serum histidine levels of the five patients in group 2 were also higher than those of the parents of patients in group 1. It is, therefore, likely that the patients in group 2 were genetically different from the parents of patients in groups 1 and 2 .

It is reported that some obligate heterozygous parents of patients with Type I hyperprolinemia show increased serum proline levels, although the reason for this is unknown (Scriver, 1978). It is not possible to decide from our data whether the patients classified in group 2 are heterozygotes for one mutant allele or homozygotes for a pair of mutant alleles. The patients in group 2 could have genetic compounds of different alleles, because the parents of patients in group 1 could not be distinguished from those of patients in group 2 on the basis of their skin histidase activities. The skin histidase activities of two patients in group 2 were more sensitive to heat denaturation than those of their parents, three parents of patients in group 1 and controls. This finding suggests that skin histidases of these two patients in group 2 may be an altered molecular form of the enzyme protein as a result of a mutation in a structural gene. Therefore, these two histidinemic patients are probably homozygotes for a pair of mutant alleles.

Histidinemia usually shows autosomal recessive inheritance. Heterozygotes for histidinemia cannot be distinguished reliably from normal homozygotes by measuring the plasma histidine response to histidine load, or even by measuring skin histidase activity spectrophotometrically (Hague and Holto, 1971; Bruckman et al., 
1970). It has been reported that the most useful way to identify heterozygotes of the autosomal recessive form of histidinemia is to measure urinary formiminoglutamic acid during the first four hours after a histidine load (LaDu et al., 1963; Rosenblatt et al., 1970). However, direct determination of histidase would theoretically be the best way of distinguishing heterozygotes from normal subjects. Matsuda et al. (1982) reported that either skin histidase activity, measured by a sensitive assay method, or urine formiminoglutamic acid, or both, can be used as genetic markers of histidinemia to a large but still limited extent.

The skin histidase activities of the parents of patients in groups 1 and 2 show a considerable scatter, as seen in the parents of patients with hyperphenylalaninemia, suggesting that they do not constitute a homogeneous group (Kaufman et al., 1975). In particular, the activities of the fathers of case 8 in group 1 and case 3 in group 2 were within the normal range.

The skin histidase activities of fifteen of sixteen parents of patients in group 1 ranged between the values for the patients in group 1 and the normal control values. The enzyme activities of five of six parents of patients in group 2 ranged between the values for patients in group 2 and normal subjects. Therefore, these parents are presumably heterozygotes in the autosomal recessive form of histidinemia. Thus most of the histidinemic families in both group 1 and group 2 seem to exhibit an autosomal recessive inheritance pattern. However, case 8 in group 1 and case 3 in group 2 may show different inheritance patterns. The mothers of these cases are presumably heterozygous carriers, while the fathers seem to be normal. Bruckman et al. (1970) found a histidinemic family with an autosomal dominant pattern. Anakura et al. (1975) reported two brothers with histidinemia, one with a classical form of the disease and the other with an atypical form: their mother was a heterozygous carrier, while their father seemed normal. From these results, they suggested that the disease in these patients might have been inherited as an $\mathrm{X}$ chromosomemodified trait, rather than as an ordinary autosomal recessive. The mode of inheritance of case 8 in group 1 and case 3 in group 2 fits to X-linked recessive inheritance, but this cannot be confirmed because these cases have no siblings.

There are some evidences that histidinemia is not a single genetic disease. Our results also indicate that patients with histidinemia, detected by screening newborn infants in Japan, can be classified into various types on the basis of the activity and the kinetic properties of skin histidase and that some cases of histidinemia exhibit different mode of inheritance, although most of histidinemia is autosomal recessive.

\section{REFERENCES}

Anakura, M., Matsuda, I., Arashima, S., Fukushima, N., and Oka, Y. 1975, Histidinemia. Classical and atypical form in siblings. Am. J. Child. 129: 858-861.

Auerbach, V.H., Digorge, A.M., and Carpenter, G.G. 1969. Histidinemia. In Amino Acid Metabolism and Genetic Variation, W.L. Nyhan, ed., McGraw-Hill Book Co., Inc., New York, pp. 145-160.

Jpn. J. Human Genet. 
Bruckman, G., Berry, H.K., and Dasenbrock, R.J. 1970. Histidinemia in two successive generations. Am. J. Dis. Child. 119: 221-227.

Gerber, D.A. 1970. Determination of histidine in serum with ophthaldialdehyde. Anal. Biochem. 34: 500-504.

Hague, R.V. and Holto, J.B. 1971. An intravenous histidine load test for the detection of heterozygotes for histidinaemia. Clin. Chim. Acta 33: 462-464.

Kacser, H., Bulfield, G., and Wallace, M. 1973. Histidinaemic mutant in the mouse. Nature 244: 77-79.

Kaufman, S., Max, E.E., and Kang, E.S. 1975. Phenylalanine hydroxylase activity in liver biopsies from hyperphenylalaninemia heterozygotes: Deviation from proportionality with gene dosage. Pediatr. Res. 9: 632-634.

Kuroda, Y., Ito, M., Ogawa, T., Takeda, E., Toshima, K., and Miyao, M. 1979. A new sensitive method for assay of histidase in human skin and detection of heterozygotes for histidinemia. Clin. Chim. Acta 96: 139-144.

Kuroda, Y., Ogawa, T., Ito, M., Watanabe, T., Takeda, E., Toshima, K., and Miyao, M. 1980. Relationship between skin histidase activity and blood histidine response to histidine intake in patients with histidinemia. J. Pediatr. 97: 269-272.

LaDu, B.N., Howell, R.R., Jacoby, G.A., Seegmiller, J.E., Sober, E.K., Zannoni, V.G., Canby, J.P., and Ziegler, L.K. 1963. Clinical and biochemical studies on two cases of histidinemia. Pediatrics 32: 216-227.

Matsuda, I., Matsuo, K., Endo, F., Uehara, I., Nagata, N., Jinno, Y., Chikazawa, S., Miyakita, T., and Miura, H. 1982. Skin histidase activity and urine formiminoglutamic acid (FIGLU) in patients with histidinemia found by screening newborn infants. Clin. Chim. Acta 119: 319 328.

Rosenblatt, D., Mohyuddin, F., and Scriver, C.R. 1970. Histidinemia discovered by urine screening after renal transplantation. Pediatrics 46: 47-53.

Scriver, C.R. 1978. Disorders of proline and hydroxyproline metabolism. In The Metabolic Basis of Inherited Disease, J.B. Stanbury, J.B. Syngaarden, and D.S. Fredrickson, eds., McGraw-Hill Book Co., New York, pp. 336-361.

Tada, K., Tateda, H., Arashima, S., Sakai, K., Kitagawa, T., Aoki, K., Suwa, S., Kawamura, M., Ohura, T., Takesada, M., Kuroda, Y., Yamashita, F., Matsuda, I., and Naruse, H, 1984. Follow up study of a nation-wide neonatal metabolic screening program in Japan. Eur. $J$. Pediatr. 142: 204-207.

Woody, N.C., Snyder, H., and Harris, J.A. 1965. Histidinemia. Am. J. Dis. Child. 110: 606-613. 